University of St. Thomas, Minnesota

UST Research Online

Marketing Faculty Publications

Marketing

2013

Informal private equity investment networks: The role of the nexus angel.

Michael C. Porter

University of St. Thomas, Minnesota, mcporter@stthomas.edu

Mark Spriggs

University of St. Thomas, Minnesota

Follow this and additional works at: https://ir.stthomas.edu/ocbmktgpub

Part of the Entrepreneurial and Small Business Operations Commons, and the Marketing Commons

This Article is brought to you for free and open access by the Marketing at UST Research Online. It has been accepted for inclusion in Marketing Faculty Publications by an authorized administrator of UST Research Online. For more information, please contact asle4660@stthomas.edu. 


\title{
Informal Private Equity Investment Networks: The Role of the Nexus Angel
}

\author{
Michael Porter and Mark Spriggs
}

\begin{abstract}
Michael Porter
is director of the Master of Business Communication Program at the University of St. Thomas's Opus College of Business in Minneapolis, MN.

mcporter@stthomas.edu
\end{abstract}

\section{MARK SPRIGgS}

is department chair at the Schulze School of Entrepreneurship at the University of St. Thomas's Opus College of Business in Minneapolis, MN. mtspriggs@stthomas.edu
$\mathrm{M}$ any fledgling businesses that need start-up capital hope for angel funding, but these entrepreneurs often lack the knowledge of, and connections to, the angel investment community. Recognizing this need, many regional and national organizations now sponsor events that offer opportunities to hear experts and investors offering wisdom on courting funds. Others provide semi-public forums for elevator pitches from entrepreneurs hoping to capture the imagination of the angel investors or venture capital firms. But these events attract only a small portion of angels in an area and rarely represent the point at which relationships begin, much less when investment decisions are made. Entrepreneurs seeking angel funding need to connect to informal angel investor networks that facilitate private equity funding.

Early stage equity investors, whom Wetzel [1983] first identified as business angels, are an important source of funding for entrepreneurial start-ups. According to the Center for Venture Research, angels invested $\$ 17.6$ billion in 57,225 ventures in 2009, down from previous years but still a significant source of funding (Sohl [2010]). This type of private equity investment often represents the bridge to progress for entrepreneurs who have exhausted internal resources but need more funding to achieve the next set of development milestones (Van Osnabrugge and Robinson [2000]). (See Morrissette's [2007] review of general characteristics of angel investors.)

But the market for angel funding has long been acknowledged as inefficient due to lack of access to potential angel investors (Sohl [1999]). Several institutional mechanisms have emerged that are targeted at improving access to angel investors and facilitating angel investment, such as business angel networks (BANs) (Knyphausen-Aufseß and Westphal [2008]; Paul and Whittam [2010]) and web-based angel portals (BeckerBlease and Sohl [2007]). These formal, more visible structures are driven by government initiatives to encourage economic development (Sørheim and Landstróm [2001]) and the desire of angel investors to participate in deals while diversifying the risk associated with these early-stage investments (Mason and Harrison [2008]).

Although BANs are important, they do not replace the more informal networks of angel investors, as many angel investors choose to remain outside of these formal, visible structures. They prefer to remain hidden from entrepreneurs seeking funding and instead participate in smaller, informal groups or syndicates of equity investors. Because of their lower level of visibility, these groups of shadowed angels rely on their personal networks and/or other members of their invest- 
ment syndicates to bring potential deals to them (Wetzel [1983]). Entrepreneurs seeking private equity funding should access the less visible, informal networks of angel investors as well as BANs.

Our research focused on understanding how an entrepreneur can identify and access these informal angel groups. Based on our findings, it appears that a few key angels (whom we call nexus angels) operate as the first point of contact for entrepreneurs and bring potential deals to hidden angels in their personal networks. Based on our interviews with angel investors and observations of funding-pitch presentations, we offer a set of preliminary findings on the role of nexus angels in informal angel syndicate funding activities.

\section{CULTURAL MEANING AND EXCHANGE IN ANGEL NETWORKS: A SOCIAL THEORY FOUNDATION}

In response to calls for additional research on angel networks (Feeney et al. [1999]; Freerar and Wetzel [1992]; Haines et al. [2003]), research models of angel investment describe an iterative, multistep business angel investment process (Fried and Hisrich [1994]; Maxwell et al. [2011]) and separate the business angel investment process into three stages: pre-investment (Amatucci and Sohl [2004]; Sørheim [2003]); the investment criteria used by business angels (Fiet [1995]; Harrison et al. [1997]); and post-investment activities of angel investors (Freerar et al. [2002]; Madill et al. [2005]). This focus on the processes of angel investment has also helped differentiate it from venture capital funding and highlighted the unique aspects of angel investment (Paul and Wyper [2007]).

One central concept manifested in angel networks relates to the crucial importance of interactions between angel investors and the entrepreneur, which are tantamount to rituals that reinforce collective membership in a broadly defined group and help achieve shared goals (Durkheim [1915]). These rituals, which are the manifestation of each party's expectations, are important to understanding the interactions leading up to the actual angel investment of capital. If these rituals are disrupted, especially by the behavior of the entrepreneur, progress toward an investment could be halted, or even terminated. This potential for trouble illustrates the importance of engaging in social interactions with a central figure willing to offer both access and counsel on the ways of the rituals.

Collins [2004] explains the necessity of such central figures-he calls them "sociometric stars," responsible for guiding social interaction. In angel investment networks, we propose that these individuals are the nexus angels. They have the necessary connections and are willing to leverage them to access private equity networks. Such boundary-spanning actors connect individual and syndicates of angels (who often invest together) by maintaining their many connections in the angel investment networks (Granovetter [1973]). To fully understand these individuals, Granovetter [2005] and Burt [1992] identify four important factors:

- the individual actors' relative position and status (i.e., centrality, access to other networks, etc.) within a network

- the strategic importance of actors and roles that provide network access, as well as access to other networks

- the mixture of both noneconomic and strictly economic activity, and the embedded manner in which most activity takes place

- bridging gaps and making connections among network members to facilitate mutually beneficial actions

The nexus angels possess the multiple ties on the boundaries of the network gap, and they have a significant understanding of, and ability to complete, the social rituals necessary to facilitate the activities of the network. Through their multitude of ties to people in the network and personal initiative, such individuals become a nexus of activity - the brokers of access, timing, and referrals within the network-creating fiscal and social capital benefits for themselves and the other actors in the group. We believe that nexus angels fulfill this important boundary-spanning role, providing entrepreneurs access to informal angel investment networks.

\section{RESEARCH}

Access to informal angel networks requires building trust among angels in a market and, given their complex social relationships, being immersed in the network to be studied. We began the research process by conducting 
informal interviews with entrepreneurs, principals of venture capital firms, and other individuals in a start-up community. Taking a grounded theory approach (Glaser and Strauss [1967]), we used loosely structured, openended questions to elicit initial responses that could uncover unexpected data and provide the opportunity for new avenues of investigation (Marshall and Rossman [1999]). Follow-up telephone interviews were conducted to corroborate and further explore certain themes generated in the initial data.

The goal was to identify and gain referrals to angel investors in the market. Referral sources identified four angel investors, and we completed formal interviews discussing their knowledge of other informal angel network members. A snowball sampling strategy was implemented to gain further access to the angel network based on their referrals, leading to in-depth, face-to-face and follow-up phone interviews with 11 acknowledged early-stage, high-growth-focused private equity investors.

In addition to interviews, we observed entrepreneurs' presentations to potential investors. These earlystage presentations were made to 12 to 18 people, many of whom were considered to be among the most active angel investors in the local network. As validation, 8 attendees were independently singled out by multiple participants when asked to name people most central to the local angel network. Detailed field notes were taken for data analysis and used in clarification interviews with the angel investors (Spradley [1980]).

For validation, several angels corroborated that what was observed closely paralleled other presentations by entrepreneurs, and discussions with individual angels after the meetings provided additional clarification. In addition, recorded follow-up calls to previously interviewed angels supported our conclusion that the presentations we observed were typical of other presentations between an entrepreneur and a group of angel investors. The transcripts of these formal conversations were then coded along with the other interview data and ultimately provided verbatim data for analysis.

\section{FINDINGS AND DISCUSSION}

The loosely structured interviews began with openended questions about core themes regarding each angel investor's entry into angel investing; their motivations for investing and other engagement with entrepreneurs; their roles before, during, and after investment; their perceptions of the deal flow, angel network, and roles of individuals in their market; and their thoughts on policy issues related to private equity investing. The angels we interviewed emerged as among the most active, recognized, and respected members of the angel community, and we eventually characterized these members as nexus angels - a finite group of the more visible angels in the network who fulfill important tasks through ties that extend widely inside and outside the network. A number of interesting themes emerged:

- nexus behaviors/identification

- connecting and presenting to nexus angels

- motivation of nexus angels

- roles of nexus angels post-investment

We highlight the essence of the data by using the verbatim responses of representative interview participants to convey these themes. (Exhibit 1 provides demographic characteristics of these individual informants.)

\section{Identifying Nexus Angels}

According to Arnie, one of the angels we interviewed, identifying nexus angels is often difficult for an entrepreneur. "To be candid with you, those people don't grow on trees. Usually I have found they are selfmade people. They are not, by and large, people who inherited wealth. Those people are usually fearful of losing the wealth they inherited... So you're looking for self-made people who oftentimes lost and made money one or more times." He also noted that a nexus angel's investments will likely be within a couple of hour's drive of their offices, which is convenient and demonstrates their interest in building their own economic communities.

Not many individuals are willing to assume the nexus angel position. In the market studied, the respondents consistently estimated that the number of "others like them in the network" was between 25 and 30 among a network of hundreds of angel investors. Wyatt explained why so take on this role: "Because it's heavy lifting. It's a lot of work for not as much reward as you would like. And I think it's because it's just an awful lot of maintaining or keeping in place a lot of moving parts. So if you're going to do this, you really have to go at it with a passion...with a mission. So there aren't 


\section{E X H I B I T 1}

\section{Characteristics of Angels Interviewed}

\begin{tabular}{|c|c|c|c|c|c|c|c|c|c|}
\hline & Age & Education & Experience & $\begin{array}{l}\text { Local } \\
\text { Native }\end{array}$ & $\begin{array}{c}\text { Tech- } \\
\text { Oriented }\end{array}$ & $\begin{array}{c}\text { Investment } \\
\text { Stage } \\
\text { Preference }\end{array}$ & $\begin{array}{c}\text { Post- } \\
\text { Investment } \\
\text { Involvement }\end{array}$ & $\begin{array}{c}\text { BAN } \\
\text { Involvement }\end{array}$ & $\begin{array}{c}\text { See Self in } \\
\text { Entrepreneur }\end{array}$ \\
\hline Betty & $60+$ & $\begin{array}{l}\text { Engineer/ } \\
\text { MBA }\end{array}$ & $\begin{array}{c}\text { Fortune } \\
50 / \text { Start-Up }\end{array}$ & No & Yes & Early to late & $\begin{array}{c}\text { Direct } \\
\text { Management }\end{array}$ & $\begin{array}{l}\text { Active; Cofounder } \\
\text { of women's } \\
\text { syndicate }\end{array}$ & Often \\
\hline Arnie & Late $50 \mathrm{~s}$ & CPA & $\mathrm{CFO}$ & No & Yes & Early & $\begin{array}{c}\text { Direct } \\
\text { Management/ } \\
\text { Board/Advisor }\end{array}$ & Limited & Generally \\
\hline Murray & $60+$ & $\begin{array}{c}\text { Undergrad/ } \\
\text { Bus. }\end{array}$ & $\begin{array}{l}\text { Start-Ups; } \\
\text { B-to-B }\end{array}$ & No & Yes & Early to late & $\begin{array}{c}\text { Direct } \\
\text { Management }\end{array}$ & Moderate & Generally \\
\hline Wyatt & Late $40 \mathrm{~s}$ & Lawyer & $\begin{array}{c}\text { M\&A } \\
\text { Attorney; } \\
\text { Managed } \\
\text { Syndicate } \\
\text { Fund }\end{array}$ & Yes & Yes & Early & Advisor & $\begin{array}{c}\text { Active; } \\
\text { Founded } \\
\text { syndicate in } \\
90 \mathrm{~s}\end{array}$ & Somewhat \\
\hline Sonny & Late $30 \mathrm{~s}$ & $\begin{array}{l}\text { Undergrad/ } \\
\text { Mktg }\end{array}$ & $\begin{array}{l}\text { Start-Up; } \\
\text { Large Cash } \\
\text { Exit }\end{array}$ & Yes & Yes & Early & Board/Advisor & Active & Often \\
\hline
\end{tabular}

that many people who want to put that kind of energy into it...but there are a handful. And there's a handful in every community."

In describing himself specifically, Wyatt captures the essence of the nexus angel: "I am sort of what the books call the connector...or the advancer. Those would be two classic labels that textbooks would say about someone like myself...which means, I like making things happen...even if I'm not the ultimate operator...I am a power networker. I really believe the network is everything." These statements suggest links to Collin's [2004] notion of the "sociometric star" and, more importantly, the strength of weak ties, posited by Granovetter [1973].

When it comes to building a syndicate of angels, Wyatt described the approach of his nexus peers: "We went out and shook the trees within our rolodexes... mostly I would say colleagues. They weren't really family. They weren't really sort of buddies who were friends." These angels were members of networks composed of other sophisticated business people who understand the risk-reward profile of venture quality investing. These activities were very much business oriented.

While no one bestows the title of nexus angel on these individuals, they eventually realize they have assumed the role. Murray noted: "So, I'd become visible in the community. In fact some other people who moved here [that] wanted to get involved in the angel community said, 'I've talked to about seven or eight people. Four of them have mentioned your name. I guess I ought to talk to you." Murray and the other participants represent a bridge or access point to the structural holes in the network (Burt [1992].

Another nexus angel, Sonny, and his business partner said they made "a conscious effort, post leaving the last company we sold, to actively network with the angel community, and there were certain key people who were already active as early-stage investor angels, and that led us to grow very quickly into meeting other people that were in these networks." Sonny did not target these key individuals: "We just were sharing our ideas and what we wanted to do next and we already knew those people were active in that community. And they helped introduce us to a series of other people. I mean now, I could probably come up with a list of 50 angels I've met as a result, but it was really spurred by three key people...now I am often the entry point...Somebody says, 'Hey, I heard you went through this path before.' And then I create an introduction to maybe five or six more people and then they grow it from there if they're 
interested in getting involved in the community. So it isn't that hard for an angel to get known to the other angels if they make even a modest effort and connect with just a few of the right people."

Part of those efforts to be engaged and enhance the local angel network was manifested in nexus participation in area BAN activity. All of our participants were involved in formal angel investment groups, and many were among the founders of one or more of these macrosyndicates, even as they continued to invest and foster microsyndicates to invest in early-stage businesses. Since the names of BAN leadership are often public, or those individuals maintain part of the public presence of the group, entrepreneurs can use this as a way to identify potential nexus angels in any given market.

To that same end, across the board, our participants made it clear that the single best way to find access to angels similar to them was by engaging with accountants and lawyers who serve entrepreneurial ventures. These professionals have contact with multiple firms and over time establish ties to nexus angels who end up as board members or guide management in the businesses they fund. Accountants and lawyers often serve a pre-vetting role in feeding potential deals to the private equity investors they have come to know. Nexus angels suggest seeking out the service providers who work with entrepreneurial businesses similar to the one an entrepreneur hopes to fund.

\section{Connecting and Presenting to Nexus Angels}

Even with a referral from a known source, such as a professional service provider, prior to allowing a presentation by an entrepreneur, many nexus angels look for symbols of entrepreneurs having succeeded in earlier activities. In Sonny's case, he relied heavily on business network websites for some clues. "The meeting I had before [our meeting], they shared 18 [connections with me]. Somehow. They're only in this market for two years and they had 18 people in their network that are in my network... clearly they've done a good job in networking." Other factors angels assess include the past experience of the principals/CEO-whether they have done this before or it is their first start-up; if their second, how successful was the first; or if the next in a series, what was the track record. They may also look for past ventures for which they have known angels who invested and reach out to them.
While certainly essential to a viable deal, the actual product or service and its value proposition often take a secondary role at this stage. Many of the angels we talked to assumed that if the deal got to them through the network, there must be some merit in the product/service. Their immediate questions to address in a presentation seemed more likely to apply to the team and the planning; whether it was something that individual angel could impact; and a reasonable plan for a profitable and timely exit.

On the day of the presentation, entrepreneurs are on their best behavior and want to make a good impression with the angels, and central to these presentations are the elements of self-presentation. Arnie describes his role in helping adjust presentations for entrepreneurs, "Typically, their stories are too long on technical detail, too short...too small on the big picture-why this is gonna be successful quickly and how the investor is gonna make a lot of money. So we try to help them translate their concepts and their message into investor English, from engineering English or entrepreneur English. Anything we can do to help in that regard is part of our catalyst program for these companies."

The nexus angel also bears the responsibility of assessing the potential of the entrepreneurs before offering them the chance to present to other angels, often using subtle cues and their own experience and gut instincts to identify the best partners. Betty spoke about an experience in which the person's true self was reflected in the way she managed her business, which came through in the presentation: "I talked to a woman the other day and the bottom line is she's about control. She won't... she hasn't shared with her employees. She really isn't going to share with her investors...consequently I've looked at it as an unbackable business."

Angels noted a general attraction to entrepreneurs that seemed receptive to feedback and coaching. Angels don't want people who are so needy that they don't cover enough bases to create a successful company, but they don't want entrepreneurs who are so independent as to be uncoachable. Murray explains, "I don't have to invest in every deal that comes in the door. I don't have to invest in any of the deals that come in the door. So there's gonna be some interpersonal relationship that goes on. Is this somebody I want to spend time with? Because you're more likely than not gonna be involved for a number of years." 
Murray looks for people who appear to be flexible and can learn; have credentials and potential for success; are competent and get things done; and in particular, have started building a team. "Starting a company is a group effort, and if you have a sole entrepreneur... your kind of nagging question is, 'Is this person a sole entrepreneur just because they're not funded yet, or is this a person who really doesn't work well with other people?' 'Why haven't they attracted other people to their vision?' You want the initial entrepreneur to be a team builder."

Sonny also offered his observations regarding interaction with entrepreneurs during the first and subsequent presentations:

"The most common thing we do is we meet, we get information and we throw it back into the water, but we stay in touch. Because one of the things that is really remarkable to us is when you throw it back in the water, which ones swim back and which ones swim back and make great progress."

"I love to give people three action items. I don't sit down with them in the meeting and say here are one, two, three things you should do. I love to interject things that they could do in the meeting and then if they are observant enough that they pick up on it... if they are executional enough that they go after and make it happen, my respect for them will change dramatically.

"[I] met somebody a year ago, I just couldn't fathom that what they were trying to do made any sense. I didn't get their vision. I didn't like their vision as much as I got it. I just didn't see them as being credible to pull it off. A year later they have built the product. They have built a heck of an advisory board. I am amazed at the people they have added to their network that this person who's a first time entrepreneur never knew and has met and people that are following his business now. It's remarkable to me and I love to see it."

Sonny notes that, in contrast, other people come back six months later without having raised any money. He often finds them trying to figure out new ways to raise money and not focusing on making progress in the business. For the nexus angel, this is a sign to stay away.

\section{Motivations of Nexus Angels}

Although the fundamental character of an investor suggests an interest in making money, Preston [2007] recognized that many angel investors also have a sense of social responsibility to the community as well as the desire to participate in the entrepreneurial process through mentoring and advising other entrepreneurs. Sullivan and Miller [1996] suggest that $22 \%$ of angels should be categorized as altruistic, because they are motivated by the prospect of investing in new firms or those creating socially beneficial products. These nonmonetary motivations held by angels enhance the picture of their motivations for engagement in the high-risk activity of private equity investment.

The nexus angels we interviewed acknowledged multiple motivations associated with informal investment activity, and they also noted it to be true in their investment networks. Betty noted that some angels, particularly those who "have been at it a very long time," focus primarily on the money and attempt to exercise heavy control of the firms they fund. But she also said that "there's no question that most of the angels get benefits...this is a way to give back...with the exception of a few that are just very money driven... a good number of the angels I can think of in town get psychic rewards for being able to help someone along the way. There's a misperception that a lot of angels are about control. They aren't about control. They're about protecting their money."

A number of the nexus angels interviewed noted a sense of personal satisfaction stemming from being part of the entrepreneurial start-up cycle. According to Arnie, "You get a combination of personal satisfaction, what some people would call bragging rights. Just a sense of accomplishment...plus the chance to make money hand over fist [in deals you do invest something]." Some considered having a personality sympathetic to the entrepreneur as important, and most relationships were fostered by the ability of the angels to see themselves in the business principals or founders.

Other psychic benefits for nexus angels included the chance to be active in "stirring things up" in the market, learning about new technologies, and contributing to the regional business environment. Wyatt expressed his perspective as one of the younger angels in the nexus of activity: "I would say helping the community is a component of it. I would say it's probably more the minority component, than the majority com- 
ponent. The majority component is I'm doing it to create a return on investment. I'm not doing this as social philanthropy. I'm not doing this as venture philanthropy. I'm doing it to create a return for my investors. I have a fiduciary responsibility...All that being said I'm passionately devoted to the concept on a macroeconomic basis of making this region strong. That is something that I think takes leadership, and I don't think there's enough of us.

"In explaining his own activity as a younger angel in the angel/entrepreneur space, Sonny echoed: "I've had great success as an entrepreneur and [I do it] just from a pay it forward standpoint." He further describes the perspective shared with a business partner, "Part of our involvement has been to say 'Wow, we can't believe [it]...we assumed everybody did it the way we did.' We were surprised at how many people gap on really, really critical pieces that are important to allowing them to be successful as entrepreneurs."

In that instance, Sonny was specifically referring to the development of complete, actionable business plans. In comparison to other participants, Sonny displayed less focus on profit taking and more on "environment building," but he still made choices that can be interpreted as being primarily profit conscious. It is worth noting that Sonny was the only nexus angel who invests more than $10 \%$ of his total investment portfolio in higher-risk angel investments. His limit is $20 \%$.

\section{Role of Nexus Angels in the Firm}

Beyond investing money, angel investors often engage in the businesses they support by contributing their expertise to the development of the funded business. Entrepreneurs look to the nexus angel for advice, in part because of their embedded, higher status in the network, but also because the nexus angel is often more accessible than others in the network.

For instance, Betty advised entrepreneurs to figure out what they want in terms of a partner: "I think in the way you present you indicate somewhat what you're looking for. What you have to be aware of is how to read the signals from the other side of the table to know if what they're offering is what you want. If all you want is money, and the strings that come attached...I guarantee you that in every case there are strings... So the real issue is figuring out what the strings are and whether or not those strings you're okay with. The question is, what kind of nurturing do they want to do? Do they want to leverage their network? As an entrepreneur, that's part of your shopping. You need to understand what they think they're going to put in and assess whether you can handle that." In nurturing these perspectives in entrepreneurs, the nexus angels prepare business principals to conform to the expectations and rituals of deal presentation and better position themselves to successfully engage angels.

Furthermore, help from an angel can act as a catalyst for the business. Entrepreneurs gain from time devoted by angels to coaching or mentoring on many levels, including how to get follow-on investments. Murray stated: "Angels can be a very valuable resource for entrepreneurs coming along. Some entrepreneurs don't realize that or think 'hey, I know everything.' I know when I started a company I was 35 . At that point, I thought I knew everything. I didn't need any help...I'm a lot stupider now."

Entrepreneurs often want to get angels involved because as founders they know they don't know what to do to make the business succeed. Murray added, "As an angel investor you're still expecting a management team that will get the job done. Somebody once told me, 'having been an entrepreneur and running companies, you've got to look at deals and say that's a pretty good idea, can I make that work? That's not the right question. Can they make it work?' You need a management team that can make it work."

Therefore, the nexus angel should be seen as a resource for advice that can greatly influence the presentation of the team. He or she can be crucial for obtaining additional rounds of financing but may not represent an overarching infusion of management to get the venture to succeed.

\section{LESSONS FOR THE ENTREPRENEUR SEEKING ANGEL FUNDING}

The purpose of this research was to explore the role of the nexus angel in informal investor networks to help guide an entrepreneur seeking angel funding. The nexus angel can provide access to hidden, informal angel investment groups and provide critical expertise for an entrepreneur to successfully attract angel funding. Based on our findings, we suggest entrepreneurs do the following to identify and work with nexus angels: 
- Network. The nexus angels we talked to place a high value on an entrepreneur's network. The assumption was that if an entrepreneur could use the network to identify influential angels, that entrepreneur could also build and leverage personal networks to make a successful business.

- Look locally. Nexus angels tend to invest in businesses that are within a few hours driving distance and are often known by local service providers (e.g., accountants, lawyers) working with entrepreneurial start-ups.

- Find angels with connections to multiple networks. Nexus angels often have connections into multiple groups. A nexus angel can identify the appropriate angel investment group for the entrepreneur, depending on the type of business, expertise/assistance required, size of investment, or other factors.

- Listen to advice on how to make the presentation. A presentation to a group of angels reflects on the nexus angel. By granting you access to the group, the nexus angel is validating the entrepreneur and the idea. The entrepreneur should listen to the nexus angel's advice on how to do an effective presentation for that specific group.

- Know what the business needs. Although nexus angels want to know the entrepreneur has a competent team, they also want to know how they can help the business (and their investment) be successful. Nexus angels can mentor an entrepreneur, provide expertise, secure critical resources, and provide other assistance. The entrepreneur must know what they need and what they are willing to accept from (or give up to) the angel investors.

\section{LIMITATIONS AND FUTURE DIRECTIONS}

The interview data we gathered, although sufficient to provide a case study perspective, needs to be validated in other settings. We identified and interviewed a number of influential angel investors, but they were all from the same geographic area. Additional studies of group dynamics and the cohesiveness of informal angel groups are also needed to further validate the nexus role.

In the past, it has been difficult to study these informal angel investment groups because many prefer to remain in the shadows. The combination of the growing number of BANs - and the knowledge that some angels participate in both public and hidden angel groups-suggests that researchers may have more access to angel investors in the future.

Unlike BANs organized or sponsored by government agencies or industry groups, nexus angels and their associated networks of angel investors have primarily individual motivations. Additional inquiry could define those motivations and determine to what degree these informal angel groups resemble or differ from the more visible BAN investors. A more complete understanding of these similarities and differences is key for entrepreneurs and researchers interested in angel funding for entrepreneurs.

\section{REFERENCES}

Amatucci, F., and J. Sohl. "Women Entrepreneurs Securing Business Angel Financing: Tales from the Field." Venture Capital, Vol. 6, No. 2/3 (2004), pp. 181-196.

Becker-Blease, J., and J. Sohl. "Do Women-Owned Businesses Have Equal Access to Angel Capital?” Journal of Business Venturing, 22 (2007) pp. 503-521.

Burt, R. Structural Holes: The Social Structure of Competition. Cambridge, MA: Harvard University Press, 1992.

Collins, R. Interaction Ritual Chains. Princeton, NJ: Princeton University, 2004.

Durkheim, E. The Elementary Forms of the Religious Life. London: Allen and Unwin, 1915.

Feeney, L., G. Haines, Jr., and A. Riding. "Private Investors' Investment Criteria: Insights From Qualitative Data.” Venture Capital, Vol. 1, No. 2, (1999), pp. 121-145.

Fiet, J., "Reliance Upon Informants in the Venture Capital Industry." Journal of Business Venturing, Vol. 10, No. 3 (1995), pp. 195-223.

Fried, V., and R.D. Hisrich. "Toward a Model of Venture Capital Investment Decision Making." Financial Management, 23 (1994), pp. 28-37.

Freerar, J., and W. Wetzel. "The Informal Venture Capital Market in the 1990's." In State of the Art of Entrepreneurship, edited by D.L. Sexton and J.D. Kasorda. Boston: PWS-Kent Publishing, 1992. 
Freerar, J., W. Sohl, and W. Wetzel. "Angles on Angels: Financing Technology-based Ventures: A Historical Perspective.” Venture Capital, Vol. 4, No. 4 (2002), pp. 275-287.

Glaser, B., and A. Strauss. The Discovery of Grounded Theory. Chicago: Aldine, 1967.

Granovetter, M. “The Strength of Weak Ties." American Journal of Sociology, Vol. 78, No. 6 (1973) pp. 1360-1380.

"The Impact of Social Structure on Economic Outcomes." Journal of Economic Perspectives, Vol. 19, No. 1 (2005), pp. 33-50.

Haines, George, J.J. Madill, and A.L. Riding. "Informal Investment in Canada: Financing Small Business Growth." Journal of Small Business and Entrepreneurship, 16 (2003), pp. 13-40.

Harrison, R., M. Dibben, and C. Mason. "The Role of Investors in Entrepreneurial Companies: A Comparison of Informal Investors and Venture Capitalists." Entrepreneurship Theory and Practice, Vol. 21, No. 4 (1997), pp. 63-81.

Knyphausen-Aufseß, D.Z., and R. Westphal. "Do Business Angel Networks Deliver Value to Business Angels?" Venture Capital, Vol. 10, No. 2 (2008), pp. 149-169.

Madill, J., G. Haines, Jr., and A. Riding. "The Role of Angels in Technology SMEs: A Link to Venture Capital." Venture Capital, Vol. 7, No. 2 (2005), pp. 107-129.

Marshall, C., and G. Rossman. Designing Qualitative Research, Third Edition. London: SAGE Publications, 1999.

Mason, C., and R. Harrison. "Measuring business angel investment activity in the United Kingdom: a review of potential data sources." Venture Capital, Vol. 10, No. 4 (2008), pp. 309-330.

Maxwell, A., S. Jeffrey, and M. Lévesque. "Business Angel Early Stage Decision Making." Journal of Business Venturing, Vol. 26, No. 2 (2011), pp. 212-225.

Morrissette, S. "A Profile of Angel Investors." The Journal of Private Equity, Summer (2007), pp. 52-66.
Paul, S., and G. Whittam. "Business Angels Syndicates: An Exploratory Study of Gatekeepers." Venture Capital, Vol. 12, No. 3 (2010), pp. 241-256.

Paul, S., and J. Wyper. "Towards a Model of the Business Angel Investment Process." Venture Capital, Vol. 9, No. 2 (2007), pp. 107-125.

Preston, S. Angel Financing for Entrepreneurs: Early-Stage Funding for Long-Term Success. San Francisco: Jossey-Bass, 2007.

Sohl, J. “The Early-Stage Equity Market in the USA.” Venture Capital, Vol. 1, No. 2, (1999) pp. 101-120.

. "The Angel Investor Market in 2009: Holding Steady but Changes in Seed and Startup Investments." Durham NH: Center for Venture Research, University of New Hampshire, March 31, 2010.

Sørheim, R. "The Pre-Investment Behavior of Business Angels: A Social Capital Approach." Venture Capital, Vol. 5, No. 4 (2003), pp. 337-364.

Sørheim, R., and H. Landström. "Informal Investors-A Categorization, with Policy Implications." Entrepreneurship and Regional Development, 13 (2001), pp. 351-370.

Spradley, J. Participant Observation. New York, NY: Holt, Reinhart \& Winston, 1980.

Sullivan, M.K., and A. Miller. "Segmenting the Informal Venture Capital Market: Economic, Hedonistic, and Altruistic Investors." Journal of Business Research, Vol. 36, No. 1 (1996), pp. 25-35.

Van Osnabrugge, M., and R. Robinson. Angel Investing: Matching Startup Funds with Startup Companies. San Francisco: Jossey Bass, 2000.

Wetzel, W. "Angels and Informal Risk Capital." Sloan Management Review, Vol. 24, No. 4 (1983), pp. 23-34.

To order reprints of this article, please contact Dewey Palmieri atdpalmieri@iijournals.com or 212-224-3675. 